\title{
HUBUNGAN ANTARA STEREOTIPE DENGAN PRASANGKA MASYARAKAT PRIBUMI PADA IMIGRAN DALAM INTERAKSI ANTAR BUDAYA DI CISARUA BOGOR
}

\section{THE RELATIONSHIP BETWEEN STEREOTYPE WITH PREJUDICE INDIGENOUS PEOPLE TO IMMIGRANTS IN CROSS CULTURE IN CISARUA BOGOR}

\author{
EN Aeni1a, Sukarelawati2 ${ }^{2}$ Agustini ${ }^{3}$ \\ ${ }^{1}$ Alumni Ps. Ilmu Komunikasi, Fakultas Ilmu Sosial dan Ilmu Politik, Universitas Djuanda \\ Bogor, ${ }^{2}$ Dosen Pembimbing I Program Studi Komunikasi, Fakultas Ilmu Sosial dan Ilmu \\ Politik, ${ }^{3}$ Dosen Pembimbing II Program Studi Komunikasi Universitas Djuanda Bogor, Jl. \\ Tol Ciawi No.1 Kotak Pos 35 Bogor 16720 \\ a Korespondensi Email: EN Aeni : efanr33@gmail.com
}

(Diterima: 07-07-2015; Ditelaah: 20-07-2015; Disetujui: 24-07-2015)

\begin{abstract}
This research is aimed to analyze the relation between stereotypes and prujudice Indigeneous people to the immigrants in cross culture in Cisarua, Bogor. In this research, the approach used is quantitative descriptive correlational method. There are 78 respondents in this research, those are the indigenous people in the village Batulayang, Cisarua Bogor. Cluster sampling technique is used in this research. The data from the questionnaires subsequently are input into the tabulation analysis manually and the they are calculated using Spearman in SPSS 18. After having correlated, the result of data analysis of $r$ xy was 0.220 shows a weak correlation. The suggestion for indigenous people and immigrants are expected to have positive stereotypes and prejudice indigenous peoples to immigrants, the indigenous people should learn the differences of the culture and the value system continuously so that gaps can be minimized in their relationship.
\end{abstract}

keywords: Stereotyping, Prejudice, Intercultural, Immigrant

\begin{abstract}
ABSTRAK
Penelitian ini bertujuan untuk menganalisis hubungan antara stereotipe dengan prasangka masyarakat pribumi pada imigran dalam interaksi antar budaya di cisarua Bogor. Pada penelitian ini pendekatan yang digunakan adalah penelitian kuantitatif dengan metode deskriptif korelasional dengan bantuan angket. Terdapat 78 responden dalam penelitian ini, yaitu masyarakat pribumi di Desa Batulayang, Cisarua Bogor. Teknik sampel yang digunakan adalah teknik cluster sampling. Data dari hasil angket selanjutnya di masukkan ke dalam tabulasi analisis secara manual dan selanjutnya dihitung dengan menggunakan range spearman pada SPSS 18. Setelah dikorelasikan, hasil dari analisa data diperoleh $r$ xy sebesar 0,220 yang menunjukkan hubungan yang lemah. Saran yang dapat diberikan kepada masyarakat pribumi dan imigran adalah diharapkan Untuk terbentuknya stereotipe dengan prasangka masyarakat pribumi yang positif pada imigran, maka masyarakat pribumi melakukan pembelajaran pada perbedaan budaya dan sistem nilai dari keduanya secara terus-menerus, sehingga dapat terminimalisir kesenjangan pada hubungan keduanya.
\end{abstract}

Kata kunci: Stereotipe, prasangka, interaksi antar budaya, imigran 
EN Aeni, Sukarelawati, Agustini. 2015. Hubungan Antara Stereotipe Dengan Prasangka Masyarakat Pribumi Pada Imigran Dalam Interaksi Antar Budaya Di Cisarua Bogor. Jurnal Komunikatio 2(1). Halaman: 45-56. 


\section{PENDAHULUAN}

Meningkatnya konflik di negara-negara Timur Tengah, Asia Tengah, Asia Barat dan Asia Selatan menimbulkan migrasi massal dengan tujuan mencari kehidupan yang lebih baik ke negara yang dianggap makmur. Hal ini yang menyebabkan pendatang menetap di Indonesia, khususnya di kawasan Cisarua, Kabupaten Bogor. Indonesia terkena dampak arus para pendatang karena letak geografis negara Indonesia yang sangat strategis sebagai perlintasan untuk negara yang mereka tuju, yaitu Australia. Para pendatang ini sebagian berasal dari Afghanistan, Myanmar, Sri Lanka, dan Somalia, yang diakibatkan konflik di Sri Lanka dan situasi hak asasi manusia di Myanmar. Mayoritas imigran berasal dari Afghanistan yang Beragama Islam syiah. Perbedaan prinsip dalam keagamaan memicu sebagian persepsi masyarakat pada imigran yang dinilai tidak religius, terlebih Bogor dikenal sebagai kabupaten yang mayoritas muslim. Dalam konteks pada kasus hubungan antarimigran dengan masyarakat pribumi, persepi mengarah pada stereotipe masyarakat yang memiliki peran penting di dalamnya. Pendatang, dalam proses menetap sementara di Indonesia, tidak dapat dihindari akan terjadinya interaksi dengan masyarakat sekitar. Hal demikian dimungkinkan akan menimbulkan persepsi ysng berbeda sehingga menimbulkan kekhawatiran demikian baik secara normatif maupun budaya serta kebiasaan bagi banyak pihak, terutaman bagi masyarakat dalam komunitas di wilayah Cisarua, Kabupaten Bogor.

Kondisi wilayah Cisarua yang masih berbentuk pedesaan yang cenderung dianggap wilayah rentan sehingga dimungkinkan masih sulit untuk menerima pendatang. Kekhawatiran demikian, sebagaimana disinggung pula oleh Heido Bogor, 2014 bahwa para pendatang ini membawa wanita non muhrim dan minuman keras serta menjadikan tempat penyelundupan prostitusi PSK kedalam wilayah tersebut, yang kategori ini menjadikan pergesekan dalam masyarakat.
Sehingga memunculkan keributan diwilayah keramaian, yang dipicu oleh adanya wanita lokal yang digoda dengan tidak sopan. Hal ini memberikan dampak sosial yang kurang bagus terhadap masyarakat.

Budaya, negara dan sistem nilai dari suatu negara yang berbeda dengan negara lain akan dimungkinkan membentuk persepsi negatif. Penulis sekiranya menjadikan stereotipe dan prasangka sebagai variabel yang menarik untuk diseleksi pada kategori sejauh mana stereotipe dapat diminimalisir efeknya pada variabel prasangka yang dimungkinkan cenderung negatif.

\section{Rumusan Masalah}

1. Bagaimana cara imigran menetap di wilayah Cisarua?

2. Bagaimana stereotipe masyarakat pribumi pada imigran?

3. Bagaimana prasangka masyarakat pribumi pada imigran?

4. Bagaimana hubungan antara stereotipe dengan prasangka masyarakat pribumi pada imigran di wilayah Cisarua Bogor?

\section{Tujuan Penelitian}

Tujuan penelitian ini adalah: 1. Mengetahui cara imigran menetap di wilayah Cisarua 2. Mengetahui stereotipe masyarakat pribumi pada imigran 3. Mengetahui prasangka masyarakat pribumi pada imigran 4. Menganalisin hubungan antara stereotipa dengan prasangka masyarakat pribumi pada imigran di wilayah Cisarua Bogor.

\section{TINJAUAN PUSTAKA}

\section{Komunikasi Antar Budaya}

Pembahasan komunikasi antar budaya, berkaitan sama dengan studi komunikasi lainnya, namun yang membedakannya yaitu adanya perbedaan budaya dan latar belakang komunikator dan komunikan. Menurut Deddy Mulyana (2005) yang terutama menandai komunikasi antar budaya adalah bahwa sumber dan penerimanya berasal dari budaya yang 
berbeda. Sehingga dalam mengkaji komunikasi antar budaya unsur pokok yang berkaitan langsung adalah konsep kebudayaan. Kebudayaan adalah cara hidup yang berkembang dan dianut oleh sekelompok orang serta berlangsung dari generasi ke generasi ( Stewart L. Tubbs dan Moss, 1996). Dalam hal ini peranan kebudayaan lebih menentukan terhadap komunikasi.

Komunikasi antar budaya sebagai suatu seni memahami dan dipahami oleh khalayak penerima berasal dari kebudayaan-kebudayaan lain (Sitaram, 1970). Dengan demikian komunikasi antarbudaya merupakan gambaran dari bentuk interaksi multidimensional antaranggota kelompok bangsa, suku bangsa, ras, dan sub-sub budaya atau subsub kelompok (Samovar, Prter dan Jain, 1985)

\section{Stereotipe Masyarakat Pribumi pada Imigran}

Psikolog Abbate, Boca, dan Boccahiaro (2004) memberikan pengertian terhadap stereotipe, yaitu susunan kognitif yang mengandung pengetahuan, kepercayaan, dan harapan si penerima mengenai kelompok sosial manusia. Stereotipe merupakan sejumlah asumsi salah yang dibuat oleh orang di semua budaya terhadap karakteristik anggota kelompok budaya lain (A. Samovar, E.Porter, R. Mcdaniel, 2010). People dan Bailey (2009) mengungkapakan setiap masyarakat memiliki stereotipe mengenai anggota, etika, dan kelompok rasial dari masyarakat yang lain.

Dapat dikatakan stereotipe merupakan gambaran kesan yang terkandung kepercayaan dan pengetahuan yang dibentuk oleh sekelompok orang terhadap kelompok yang lainnya berdasarkan asumsi yang salah. Dengan demikian, stereotipe masyarakat imigran dari masyarakat pribumi dimungkinkan merupakan klasifikasi fakta tentang masyarakat pribumi atau penilaian masyarakat pribumi yang tidak benar.

Menurut A. Samovar, E.Porter, R. Mcdaniel (2010) stereotipe dapat berubah ketika anggota dari kelompok yang berbeda meningkatkan interaksi mereka satu sama lainnya. Melalui interaksi ini, stereotipe fiksi dan negatif dapat dibuktikan salah. Hal ini mengacu kepada proses adaptasi bagaimana frekuensi interakasi terhadap budaya lain. Pengaruh dan pentingnya untuk beradaptasi pada budaya dinyatakan oleh Kosic dan Phalet (2006) migrasi internasional menciptakan masyarakat yang berbeda secara budaya dan etnis. Ketika orang-orang dari budaya yang berbeda saling berinteraksi, mereka tidak hanya menghadapi sistem kepercayaan, nilai, kebiasaan, dan perilaku yang berbeda, nsmun sayangnya juga prasangka satu dengan lainnya. Kelihatannya hubungan sosial antara imigran dan penduduk lokal kadang kurang padu dan seringkali menunjukkan rasa permusuhan yang kuat atau bahkan rasisme dibalik rasa toleransi. Sebagaimana yang telah disinggung tentang adaptasi. Menurut Schneider (dalam Partosuwido, 1993) adaptasi atau penyesuaian diri merupakan kemampuan untuk mengatasi tekanan kebutuhan, frustasi dan kemampuan untuk mengembangkan mekanisme psikologis yang tepat. Menurut Callhoun dan Acocella (dalam Sobur, 2003) penyesuaian dapat didefenisikan sebagai interaksi individu yang kontinu dengan diri individu sendiri, dengan orang lain, dan dengan dunia individu. Begley (dalam Samovar, Porter, dan Mcdaniel, 2006) mengungkapkan bahwa, meskipun wawasan dan pengetahuan budaya dapat dikumpulkan melalui pembelajaran sebelumnya, namun pengalaman akan bertambah melalui percakapan setiap harinya dengan orangorang di lingkungan baru.

Dalam proses adaptasi, dimungkinkan untuk terjadinya asimilasi karena sikap keterbukaan dan saling pengertian menjadi jembatan, jika salah satu dari dua kebudayaan yang berbeda mengubah sifat khas dari unsur-unsur kebudayaannya dan menyesuaikan dengan kebudayaan dari kelompok lainnya. Menurut Koentjaraningrat (2009) Asmilasi adalah proses sosial yang timbul bila ada: (a) golongan-golongan manusia dengan latar belakang kebudayaan yang berbeda-beda (b) saling bergaul langsung secara intensif 
untuk waktu yang lama sehingga (c) kebudayaan-kebudayaan golongan tadi masing-masing berubah sifatnya yang khas, dan juga unsur-unsurnya masing-masing berubah wujudnya menjadi unsur-unsur kebudayaan campuran. Terdapat faktorfaktor yang menjadi penghambat dalam proses asimilasi yang pernah diteliti oleh para ahli, yaitu bahwa hanya dengan pergaulan antara kelompok-kelompok secara luas dan intensif saja, belum tentu terjadi proses asimilasi, kalau di antara kelompok-kelompok yang berhadapan itu tidak ada suatu sikap toleransi dan simpati satu terhadap yang lain. Jadi, adaptasi adalah proses penyesuaian secara terusmenerus dalam mempelajarai budaya baru.

Menurut Koentjaraningrat (1996; 145147) proses enkulturasi adalah proses belajar dan menyesuaikan alam pikiran serta sikap terhadap adat, sistem norma, serta semua peraturan yang terdapat dalam kebudayaan seseorang. Proses ini telah dimulai sejak awal kehidupan, yaitu dalam lingkungan keluarga, kemudian dalam lingkungan yang makin lama makin meluas. Pada awalnya seorang anak kecil mulai belajar dengan cara menirukan tingkah laku, orang-orang disekitarnya, yang lamakelamaan menjadi pola yang mantap, dan norma yang mengatur tingkah lakunya "dibudayakan". Selain dalam lingkungan keluarga, norma-norma tersebut dapat pula dipelajari dari pengalamannya bergaul dengan sesama warga masyarakat.

Menurut Poole (2002) enkulturasi adalah suatu proses sosial melalui mana manusia sebagai mahluk yang bernalar, punya daya refleksi dan inteligensia, belajar memahami dan mengadaptasi pola pikir pengetahuan, dan kebudayaan sekelompok manusia lain. Refleksi yang diartikan sebagai penangkis, jika dimungkinkan secara tiba-tiba pada hal yang sifatnya prinsip, dapat menolak untuk tidak terpengaruh.

\section{Prasangka Masyarakat Pribumi pada Imigran}

Prasangka adalah sifat negatif terhadap suatu kelompok dan para nggota dari kelompok tersebut. Sears dkk, Baron, Byrne dan Suls (dalam Budi Susetyo, 2010) Sebagai fenomena sikap, prasangka dapat dilihat memiliki tiga komponen utama yaitu: 1) komponen afektif: berisi perasaan ataupun emosi negatif terhadap kelompok. 2) komponen kognitif: meliputi keyakinan yang bervalensi negatif terhadap kelompok. 3) komponen behavioral: yang menunjuk pada pengalaman behavioral dengan kelompok. Menurut Myers (1993) evaluasi negatif yang menandai prasangka dapat berasal dari asosiasi-asosiasi yang bersifat emosional, dari kebutuhan untuk membenarkan perilaku ataupun dari keyakina negatif yang disebut dengan stereotipe.

Macionis (1998) Prasangka merupakan generalisai kaku dan menyakitkan mengenai sekelompok orang. Prasangka menyakitkan dalam arti bahwa orang memiliki sikap yang tidak fleksibel yang didasarkan atas sedikit atau tidak ada bukti sama sekali.

Allport (dalam Haslam dkk, 1995) juga mengemukakan bahwa stereotipe bertanggungjawab atas terjadinya prasangka sosial. Allport memberikan contoh, bahwa orang-orang Eropa yang belum begitu mengenal orang Amerika selalu mengganggap semua orang Amerika memiliki sifat bersahabat dan peduli pada orang lain. Padahal tidak semua orang Amerika memiliki sifat-sifat tersebut. Menurut A. Samovar, E.Porter, R. Mcdaniel, (2010) bahwa prasangka terjadi ketika seseorang memiliki generalisasi terhadap sekelompok orang atau hal-hal, sering kali didasarkan pada sedikit atau tidak adanya pengalaman faktual. Prasangka dapat menjadi postif (menyukai kelompok tertentu atau suatu hal) atau negatif (tidak menyukai kelompok tertentu atau suatu hal).

Dari hal yang telah diuraikan di atas secara tidak langsung Allport mengatakan bahwa arah prasangka sebenarnya bisa positif dan negatif. Hanya saja menurut Brown (2005) prasangka positif biasanya tidak menimbulkan masalah dalam hubungan antarpribadi dan antarkelompok sehingga tiak dibicarakan secara khusus atau bahakan dianggap tidak ada.

Jadi, prasangka postif dapat digambarkan sebagai hubungan yang tidak mengalami masalah dalam kelompok karena 
komunikasi dapat dibangun secara harmonis yang dibangun oleh tiap individu dengan membuka diri, terhadap kondisi demikian dalam komunikasi antarbudaya. Dengan terus membangun hubungan personal yang bersifat harmonis,maka level prasangka akan menuju ke arah yang positif. Menurut Luhulima (2006) Harmonisasi adalah suatu proses upaya menuju harmoni. disharmoni yaitu adanya kejanggalan atau ketidakserasian, yang merupakan alasan mengapa diperlukan dan diupayakan harmonisasi. Harmoni adalah keselarasan; keindahan. Dengan kenyataan itu maka pengetahuan harmoni akan terbentuk pada dua kemungkinan; selaras atau tidak selara; indah atau tidak indah. (Banoe, 2003). Menurut Samovar, Porter, dan Mcdaniel, (2010) keharmonisan merujuk pada rasa harga diri dan penghargaan diri. Dalam berinteraksi dengan orang lain, hal ini berarti diperlakukan sebagai seseorang dibandingkan sebagai suatu objek

Jadi, harmonisasi dalam suatu hubungan adalah suatu upaya untuk menghadirkan suatu keselarasan dengan menyeimbangkan segala aktivitas dalam berinteraksi satu sama lain dengan cara peduli terhadap perasaan orang lain untuk mencipatakan hubungan yang baik.

Prasangka negatif merupakan sikap yang ditunjukan oleh seseorang dalam berkomunikasi berupa penolakan dikarenakan oleh ketidaksukaan atau tidak sependapat sehingga menutupi kebenaran tanpa mempertimbangkan berdasarkan pada fakta. Seseorang yang memiliki prasangka tidak berusaha untuk melakukan proses belajar ke arah pengambilan keputusan yang merugikan orang lain dan dirinya sendiri karena rasa tidak suka. Penolakan mengindikasikan tidak menerima dan mencegah hubungan diantara keduanya, melalui perasaan tidak suka yang menunjukkan ketidakpedulian sehingga cenderung menutupi fakta dengan menyembunyikan dan merahasiakan fakta yang terjadi terhadap aktivitas apapun dalam lingkungan masyarakat.

\section{Hubungan Stereotipe dengan Prasangka Masyarakat Pribumi pada Imigran}

Tjfel 1982 (dalam Budi Susetyo, 2010)) menjelaskan bahwa dalam relasi antarkelompok tidak jarang terjadi suatu proses yang disebut persepsi ketidakadilan yaitu ketika anggota suatu kelompok mempersepsikan terjadinya kecurangan atau ketidakadilandalam hubungan antara kelompoknya dengan kelompok lain. Dalam teori social comparison dijelaskan bahwa dalam hubungan antarkelompok maka pembandingan status, kekuatan dan dominasi menjadi pertimbangan utama yang menentukan bentuk relasi. Dengan demikian ketika dalam relasi tersebut dipersepsikan terjadi perbandingan yang tidak seimbang (insecure comparison) maka persepsi tentang terjadinya relasi yang penuh kecurangan dan ketidakadilan ini muncul. Selanjutnya dikemukakan oleh Tajfel (dalam Hogg dan Abram, 1988) stereotipe lebih dinyatakan dalam bentuk permusuhan ketika tekanan sosial terjadi dalam hubungan antarkelompok.

Streotipe yang berlebihan akan memunculkan prasangka terhadap orang atau kelompok lain tergantung dari pengetahuan terhadap orang atau kelompok tersebut (dalam hal ini stereotipe didasarkan atas pengetahuan atau kognitif), namun masih dalam tataran sikap (belum tindakan). Sedangkan sikap berprasangka yang berlebihan dapat memunculkan perlakuan yang diskriminatif (sudah dalam tataran perilaku). Jadi prasangka merupakan disposisi dari stereotipe.

\section{Imigran di Indonesia}

Setiap pendatang yang datang ke suatu negara, tidak semua memiliki tujuan untuk bermigrasi dengan motif ekonomi. Menurut M. Iman Santoso (2004) Imigrasi berasal dari bahasa latin migratio yang berarti perpindahan orang dari suatu tempat atau negara menuju ke tempat ata negara lain. Namun, dalam konteks ini terdapat perbedaan dalam hal imigran yang motif ekonomi untuk mencari kehidupan yang lebih baik dengan yang keluar dari wilayahnya karena merasa terancam hidupnya. Kategori kedua disebut dengan pengungsi, yaitu sebagai kelompok orang yang rentas (vulnerable persons). Menurut 
Ahmed Abou-El-Wafa (2009) Seseorang dapat dikualifikasikan sebagai pengungsi manakala: Pengungsi berbeda dari orang yang bermigrasi di wilayah negara dan orang yang bermigrasi dengan motif ekonomi (migran ekonomi).

\section{Imigran Menetap di Cisarua, Bogor}

Menurut UNHCR, Indonesia sendiri tidak tergolong sebagai negara tujuan pengungsian. Mayoritas dari mereka menjadikan Indonesia sebagai negara transit untuk melanjutkan perjalanan ke Australia. Permasalahan ini tidak hanya menjadi diskursus bagi negara yang meratifikasi Konvensi tentang Status Pengungsi, 28 Juli 1951 (selanjutnya disebut Konvensi 1951) beserta Protokolnya 31 Januari 1967, tapi juga dunia, bahkan Indonesia yang sama sekali tidak dibebani tanggung jawab konvensi tersebut.Walaupun Indonesia pernah berpartisipasi dengan menyediakan Pulau Galang di Kepulauan Riau sebagai penampungan pengungsi asal Vietnam dan Cambodia (tahun 1979-1996) atas mandat dari PBB (source : UNHCR). Disamping Pulau Galang, pulai lian seperti Natuna, Tarempa dan Anambas juga menjadi tempat transit dan pemprosesan manusia perahu.

Data yang dirilis oleh UNHCR per tahun 2014, jumlah imigran ilegal yang tinggal di Rumah Detensi Imigrasi (Rudenim) seluruh Indonesia mencapai 8.262 orang. Sementara yang sudah memegang status pengungsi dan bisa tinggal di penampungan sebanyak 2.078 orang. Jumlah pencari suaka di Indonesia setiap tahun mengalami peningkatan. Pada tahun 2008, pencari suaka ke Indonesia masih berkisar 385 orang, sedangkan tahun 2013 sudah mencapai 8.332 orang. Adapun total imigran ilegal yang berada di wilayah Indonesia sampai bulan Maret 2014 kurang lebih sekitar 10.623 orang yang terdiri dari 7.218 orang pencari suaka dan sisanya 3.405 berstatus pengungsi. Angka tersebut diyakini akan semakin meningkat, mengingat konflik di negara bagian Afrika dan Asia terus berlangsung.

Cisarua menjadi salah satu tempat bermukimnya para imigran, yang penyebarannya di beberapa kampung. Biasanya mereka tinggal berkelompok dengan menempati rumah kontrakan yang disewakan oleh penduduk setempat dan mayoritas mereka adalah laki-laki paruh baya. Menurut data yang diliris pihak setempat, jumlah imigran yang terdata pada tahun 2014, khususnya di Desa Batulayang sebanyak 424 orang. Alasan dari para pencari suaka dan pengungsi mendiami Cisarua adalah karena lingkungannya yang dianggap mendukung dengan cuacanya yang sejuk serta biaya hidupnya cenderung lebih murah dibandingkan dengan dikotakota besar lainnya seperti, Jakarta. Disamping itu, mereka mudah untuk membeli kebutuhan pangan, karena di Cisarua banyak toko yang menjual bahan makanan asal Timur Tengah.

\section{MATERI DAN METODE}

Penelitian ini menggunakan metode deskriptif korelasional dengan pendekatan kuantitatif. . Kuantitatif adalah riset yang menggambarkan atau menjelaskan suatu masalah yang hasilnya dapat digeneralisasikan. Dalam penelitian ini peneliti menggunakan teknik sampling Cluster Sampling, yang merupakan teknik pengambilan sample dengan cara membagi populasi dalam satuan-satuan sampling. Cluster Sampling digunakan untuk menentukan sample bila obyek yang akan diteliti atau sumber data sangat luas. Untuk menentukan penduduk mana yang akan dijadikan sumber data, maka pengambilan sampelnya berdasarkan daerah populasi yag telah ditetapkan (Sugiyono, 2011).

Populasi yang di ambil dari penelitian ini adalah masyarakat di Kp. Batu Kasur RT 01 RW 04 Kelurahan Batulayang, Cisarua Bogor dengan jumlah 79 keluarga. Mayoritas imigran tinggal di Desa Batulayang, sehingga masyarakat Desa Batulayang lebih banyak melakukan interaksi dengan imigran, dan akan lebih efektif apabila mengambil populasi di wilayah ini. 


\section{HASIL DAN PEMBAHASAN}

Tabel 1. Hubungan Antara Variabel X Stereotipe dengan Variabel Y Prasangka masyarakat Pribumi pada Imigran dalam Interaksi Antar Budaya di Cisarua Bogor

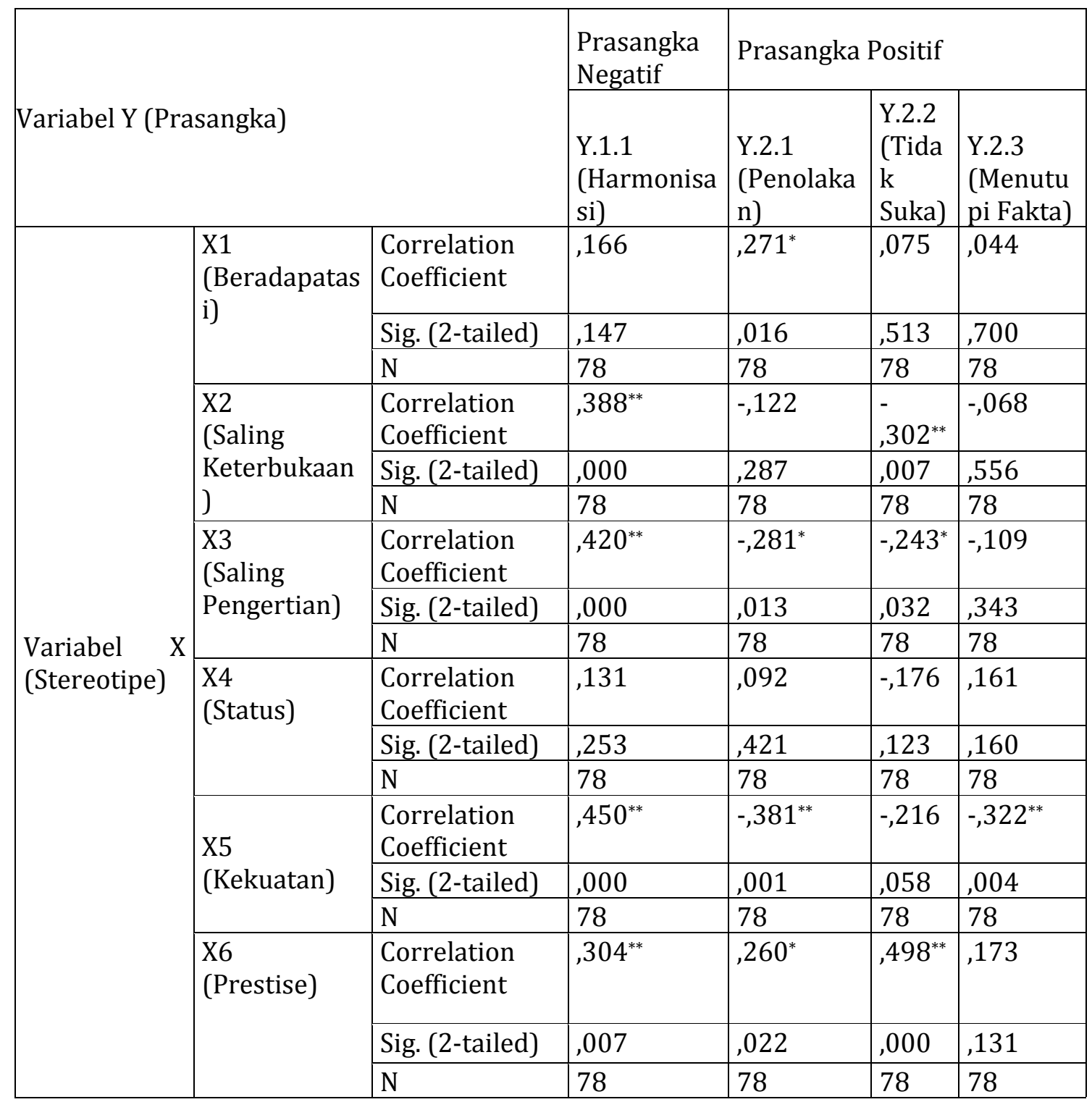

*. Correlation is significant at the 0.05 level (2-tailed).

**. Correlation is significant at the 0.01 level (2-tailed).

Berdasarkan data pada tabel diatas, diketahui hubungan variabel stereotipe yang diuraikan dalam indikator, memilki nilai koefisien korelasi berkisar antara 0 sampai 1 atau 0 sampai -1 . Semakin mendekati 1 atau -1 maka hubungan semakin erat. Jika mendekati 0 maka hubungan semakin lemah.

1. Beradaptasi memiliki hubungan yang signifikan dengan penolakan. Masyarakat pribumi mengalami proses penyesuaian dalam mempelajari budaya 
baru, dengan berinteraksi dengan imigran. Namun, adanya sikap menghindari dari masyarakat pribumi karena adanya perbedaan dalam hal bahasa. Dan adanya sikap acuh yang ditunjukkan imigran kepada masyarakat pribumi.

2. Saling keterbukaan memiliki hubungan yang sangat signifikan dengan harmonisasi dan tidak suka. Masyarakat pribumi memiliki sikap terbuka melakukan interaksi dengan imigran secara objektif terhadap hal-hal yang disukai dan tidak disukai, berupa keterus terangam tentang berbagai hal sehinga terjadi keselarasan hubungan diantara keduanya. Keterbukaam masyarakat pribumi pada hal-hal yang tidak disukai pada imigran, maka dalam menanggapi hal tersebut, dapat terjadinya ketidak pedulian pada masyarakat pribumi.

3. Saling pengertian memiliki hubungan yang sangat signifikan dengan harmonisasi. Telah terjadi saling memahami masyarakat pribumi dengan imigran sehingga terciptanya harmonisasi diantara keduanya. Masyarakat pribumi dengan imigran terjadi saling memahami dengan menunjukkan penolakan untuk hal yang tidak disukai. Dalam hal ini, masyarakat pribumi dengan imigran dapat hidup saling berdampingan dalam berbagai hal.

4. Status memiliki hubungan yang negatif dengan harmonisasi, penolakan, tidak suka, dan menutupi fakta. Hal ini karena, meskipun pada dasarnya masyarakat pribumi hidup berdampingan dengan imigran untuk saling memahami, tetapi kecendrungan kebersamaan di antara keduanya tidak akan mempengaruhi masyarakat pribumi dalam memberikan kesempatan kepada imigran untuk menduduki jabatan atau ikut serta dalam organisasi masyarakat.

5. Kekuatan memiliki hubungan yang sangat signifikan dengan harmonisasai. Hal ini karena harmonisasi diantara masyarakat pribumi dengan imigran di tandai dengan kuatnya masyarakat pribumi dalam mengontrol perbedaan ataupun permasalahan atau kesenjangan di keduanya. Kekuatan memiliki hubungan yang sangat signifikan dengan penolakan dan menutupi fakta. Hal ini karena, bertentangan dengan temuan sebelumnya tentang keterbukaan pribumi pada hal yang disukai atau tidak disukai. Hasil penelitian menunjukkan masyarakat pribumi masih setengah hati menyembunyikan fakta atau dapat diasumsikan sebagai segala hal kenyataan yang terjadi pada masyarakat pribumi untuk menolak menyampaikan kepada pihak imigran secara terbuka pada hal yang telah terjadi.(Hasil wawancara terlampir)

6. Prestise memiliki hubungan yang sangat signifikan dengan harmonisasi. Hal ini karena, masyarakat pribumi dapat menjaga harmonisasi dengan imigran, hal tersebut digambarkan dari hasil penelitian bahwa masyarakat pribumi dapat memberikan penghargaan atau kehormatan kepada imigran sepanjang imigran memiliki prestasi. Prestise memiliki hubungan yang signifikan dengan penolakan dan tidak suka. Hal ini karena, menguatkan pada poin sebelumnya, gambaran tersebut menguatkan pada hal yang tidak disukai oleh masyarakat pribumi terhadap imigran sehingga pihak pribumi tetap menolak untuk memberikan penghargaan atau hadiah walaupun pihak imigran memiliki prestasi. 
Tabel 2. Hasil SPSS Hubungan Stereotipe dengan Prasangka Masyarakat Pribumi pada Imigran dalam Interaksi Antar Budaya di Cisarua Bogor

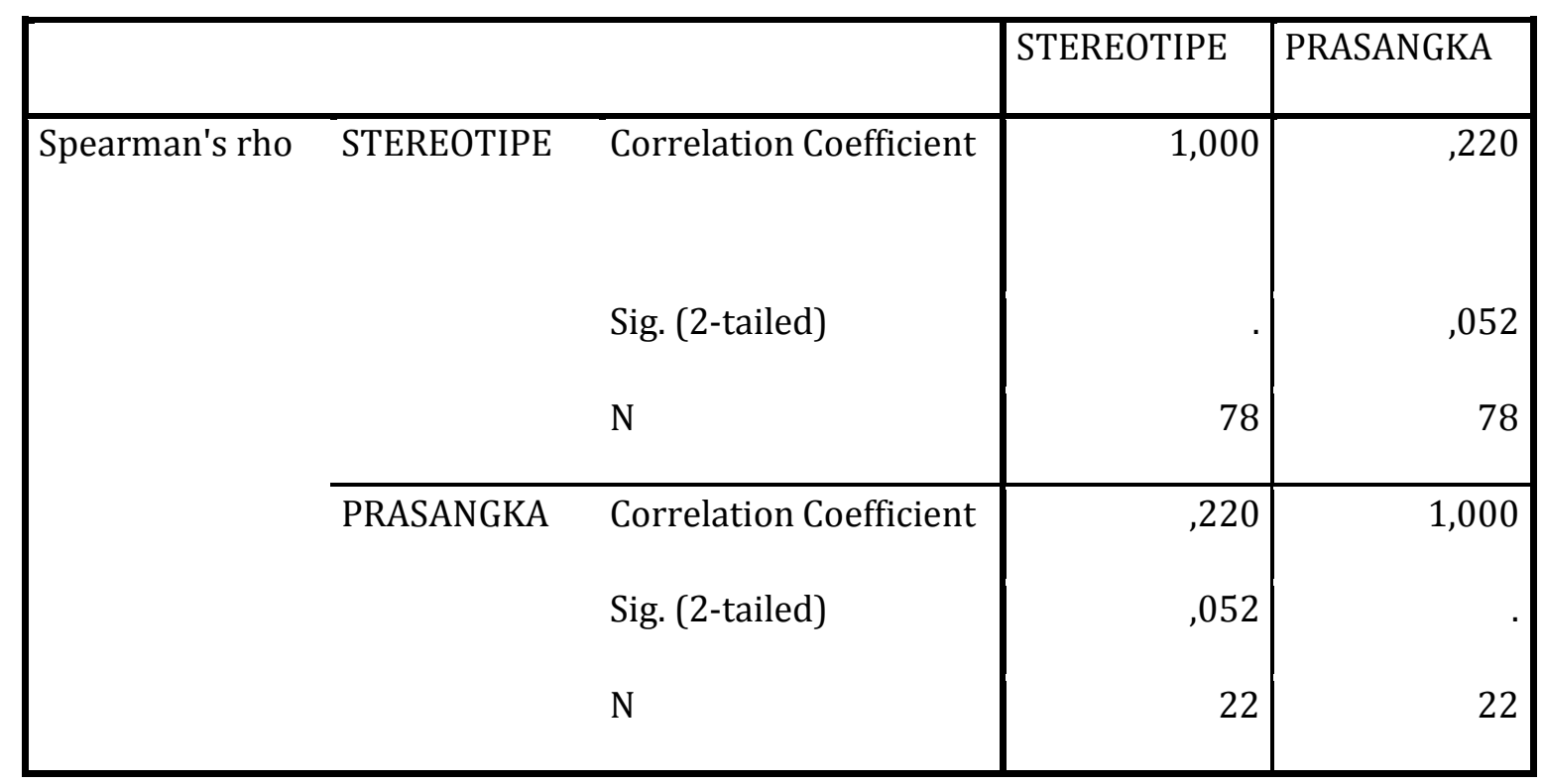

Berdasarkan di atas analisis rank spearman hubungan stereotipe dengan prasangka didapat koefisien sebesar 0,220. Jika dilihat pada pedoman interpretasi koefisien korelasi, dimana nilai koefisien korelasi (r) didapat sebesar 0,220 yang terletak diantara wilayah 0,20-0,399 yang berada di level rendah, maka dapat disimpulkan bahwa korelasi diantara kedua variabel $\mathrm{X}$ (stereotipe) dan variabel $\mathrm{Y}$ (prasangka) memiliki hubungan yang lemah. Hubungan yang rendah menggambarkan masyarakata pribumi tetap menerima kehadiran imigran untuk menetap berdampingan, sepanjang imigran dapat menyesuaikan sikapnya terhadap kebudayaan dan menghormati aturan serta nilai yang berlaku di lingkungan masyarakat pribumi. Dalam komunikasi antar budaya yang menjadi sumber dan penerimanya adalah berasal dari budaya yang berbeda. Masyarakat pribumi dan imigran memiliki cara hidup yang berkembang dan dianut secara berbeda. Oleh karena itu pada hakekatnya dalam berkomunikasi antara masyarakat pribumi dengan imigran yang melibatkan unsur kebudayaan, maka munculnya enkulturasi dan asimilasi. Pada proses enkultarasi, dimana masyarakat pribumi berusaha untuk dapat hidupa saling berdampingan dengan imigran, namun pada hal yang bersifat prinsip, tidak terpengaruh untuk melakukan hal tidak perlu dilakukan. Pada awal kedatangan ke wilayah Cisarua, imigran tidak mengetahui nilai dan norma yang di anut dalam masyarakat pribumi, sehingga seringkali muncul kesalahpahaman yang berujung konflik. Hal ini salah satunya, perlakuan tidak sopan imigran terhadap wanita pribumi. Untuk dapat hidup rukun berdampingan adanya proses asimilasi dengan pembelajaran menyesuaikan di antara unsur-unsur kebudayaan yang berbeda di antara masyarakat pribumi dengan imigran, sehingga bertambahnya wawasan dan pengetahuan budaya yang dikumpulkan melalui pengalaman dan proses komunikasi setiap harinya, sehingga imigran menyadari hal yang benar dan tidak benar untuk dilakukan.

Demikian, adanya kesepakatan diantara keduanya untuk saling menghormati dan bertoleransi dalam berasimilasi untuk meredam konflik yang pernah terjadi. Dan berdasarkan hal tersebut, masyarakat pribumi memiliki prasangka positif berupa adanya kerukunan, bertenggang rasa, kenyamanan dalam berinteraksi dan menjunjung rasa kebersamaan dengan imigran. Namun, apabila imigran melanggar kesepakatan yang telah di setujui bersama dan berperilaku menyimpang 
dengan norma yang di junjung dalam masyarakat pribumi, maka dimungkinkan akan kemunculan prasangka yang negatif, yang menimbulkan kebencian, menghindar untuk berinteraksi, merasa terancam, berburung sangka, dan menghindari bekerja sama dengan imigran. Oleh karena itu, jika adanya hubungan personal yang bersifat positif antara masyarakat pribumi dengan imigran, maka akan semakin lemah level prasangka yang terjadi, serta melalui proses pembelajaran dan penyesuaian setiap harinya secara terusmenerus dimungkinkan prasangka berubah ke arah yang positif.

\section{KESIMPULAN DAN SARAN}

\section{Kesimpulan}

Berdasarkan uraian hasil penelitian pada babbab sebelumnya tentang hubungan streotipe dengan prasangka masyarakat pribumi pada imigran, maka dapat disimpulkan sebagai berikut : 1 . Stereotipe masyarakat pribumi pada imigran, cukup positif, namun masyarakat pribumi masih setengah hati untuk terbuka secara objektif menyampaikan hal yang di sukai atau tidak di sukai kepada imigran di karenakan masih di temukan kasus, kaum pribumi telah menjarah benda-benda milik imigran. 2. Bentuk prasangka masyarakat pribumi pada imigran, cukup baik sehingga masyarakat pribumi memiliki kontrol dalam mengendalikan kesenjagan dengan imigran dan untuk hal yang bersifat prinsip, tidak ada toleransi untuk terpengaruh pada hal-hal yang di temukan diantara keduanya. 3. Dalam komunikasi antar budaya pada masyarakat pribumi dengan imigran, adanya proses enkultrasi dan asimilasi yang terjadi. 4 . Hubungan stereotipe dengan prasangka masyarakat pribumi pada imigran adalah lemah. Artinya, relasi antar keduanya masih berlangsung wajar, namun masih tergambar batasan diri pada masyarakat pribumi. Pada konteks dapat saling memahami satu sama lain sehingga terjadi harmonisasi yang terbuka untuk hal-hal tertentu tetapi pada hal yang tidak disukai, salah satunya tentang prinsip seperti keagamaan, maka masyarakat pribumi dapat menolak pada hal yang menyimpang dari norma masyarakat.

\section{Saran}

2. Untuk terbentuknya stereotipe dengan prasangka masyarakat pribumi yang positif pada imigran, maka masyarakat pribumi melakukan pembelajaran secara terus-menerus dengan proses enkulturasi dan asimilasi, sehingga dapat terminimalisir kesenjangan pada hubungan keduanya.

3. Sebagaian besar imigran yang datang ke Cisarua tidak mengetahui budaya warga setempat, maka dibutuhkannya pendidikan kebudayaan pribumi untuk imigran.

4. Segala hal yang menyangkut prinsip yang ada pada diri pribumi untuk dapat dipertahankan atau dapat dikuatkan sebagai bentuk kontrol sosial dalam menolak pengaruh pada hal yang tidak perlu dilakukan oleh pribumi.

\section{DAFTAR PUSTAKA}

Andersen, L Margareth \& Tayor, F. Howard. 2006. Sosiology: Understanding a Diverse Society, Fourth Edition. Belmont: Thomson Wadsworth

Banoe, Pono. 2003. Pengantar Pengetahuan Harmoni. Yogyakarta: Kanisus.

Henslin, M. James. 2015. Essentials of Sosiology 11th Edition. New Jersey: Person Education, Inc,.

Hornby, A.S \& Cowie, A.P. 2007. Oxford Advanced Learner's Dictionary of Current English Hardcover. Oxford: Oxford University Press.

Koentjaraningrat. 2009. Pengantar Ilmu Antropologi. Jakarta: PT. Rineka Cipta

Liliweri, Alo. 2007. Makna Budaya dalam Komunikasi Antar Budaya. Yogyakarta: LkiS.

Martin, A. Elizabeth \& Law, Jonathan. 2009. A Dictionary of Law (Oxford Paperback Reference). Aylesbury: Market House Books.

Maryati, Kun \& Suryawati, Juju. 2006. Sosiologi untuk SMA dan MA Kelas X. Jakarta: Esis. 
Mulyana, Deddy. 2005. Komunikasi Bisnis Lintas Budaya. Bandung: PT. Remaja Rosda Karya.

Nazir, Moh. 2011. Metode Penelitian. Bogor: Ghalia Indonesia.

Samovar, A. Larry, Porter, E. Richard, McDaniel, Edwin R. 2010. Komunikasi Lintas Budaya, Edisi 7. Jakarta: Salemba Humanika.

Santoso, M. Imam. 2005. Perspektif Imigrasi dalam Pembangunan Ekonomi dan Ketahanan Nasional. Jakarta: UI Press.

Sihabudin, Ahmad. 2007. Komunikasi Antarbudaya: Satu Perspektif MultiDimensi. Serang: Departemen Ilmu Komunikasi FISIP-Untirta.

Sugiyono. 2011. Metode Penelitian Administrasi. Bandung: Alfabeta.

Susetyo, D.P Budi. 2010. Stereotipe dan Relasi Antar Kelompok. Yogyakarta: Graha Ilmu.

Ruhimat, Mamat, Kosim \& Supriatna, Nana. 2006. Ilmu Pengetahuan Sosial (Geografi, Sejarah, Sosiologi, ekonomi). Bandung: Grafindo Media Pratama.

\section{Media Online}

http://www.unhcr.or.id/id/

http://jrs.or.id/ http://muhammadalvisyahrin.blogspot.com/2 014/07/indonesia-darurat-imigranilegal.html . Indonesi Darurat Imigran Ilegal. Diakses pada minggu 20 juli 2014 pukul 21:36

http://kucingracing.blogspot.com/2013/03/no rmal-0-false-false-false-in-x-none-x.html Makalah Imigran Gelap di Indonesia. Diakses pada sabtu 16 maret 2013 pukul 01.36

(http://heibogor.com/detail/6962-KecamatanCisarua-Minta-Imigran-Dilokalisasi

Kecamatan Cisarua Minta Imigran Dilokalisasi. diakses pada Kamis 11 Desember 2014 pukul 17:15

http://almachaniago.blogspot.com/2013/03/i nteraksi-sosial-memunculkan-

berbagai.html Interaksi Sosial Memunculkan Berbagai Corak Stereotipe dan Prasangka yang Berakibat Adanya Diskriminasi. Diakses pada 2 Maret 2013 pukul 12:34

http://www.kabarpublik.com/2012/05/warga -puncak-tolak-imigran/

Warga Puncak Tolak Imigran. Diakses pada 15 $\underline{\text { Mei } 2011}$ 